\title{
Cyanobacteria and macroalgae in ecosystem of the Neva estuary
}

\author{
V.N. Nikulina ${ }^{(1)}$, Y.I. Gubelit ${ }^{(1)}$ \\ Received December 3, 2010 \\ Revised May 24, 2011 \\ Accepted May 30, 2011
}

\section{ABSTRACT}

Key-words: phytoplankton, macroalgae, eutrophication, Planktothrix agardhii, Cladophora glomerata
The Baltic Sea and Neva estuary are plagued by coastal eutrophication. In order to estimate the scale of the problem, quantitative estimates of phytoplankton and macroalgal mats were determined in the Neva estuary. Long-term monitoring (1982-2009) of phytoplankton showed changes in its species composition and abundance. Summer phytoplankton biomass increased significantly in the 1990s, with concomitant changes in species composition, despite a decline of nutrients in the Neva estuary. The cyanobacteria Planktothrix agardhii became a dominant species. The summer biomass of phytoplankton reached a maximum of $5.2 \pm 0.4 \mathrm{mg} \cdot \mathrm{L}^{-1}$ in 2002-2004. Monitoring of macroalgal community in the coastal area of the Neva estuary from 2002 to 2009 showed the dominance of the filamentous green alga Cladophora glomerata in the phytobenthos. Average biomass of macroalgae in inner and outer estuary differed significantly at $132 \pm 29$ and $310 \pm 67 \mathrm{~g} \mathrm{DW} \cdot \mathrm{m}^{-2}$, respectively. This study showed, that fluctuations in macroalgal biomass reflected human influence on estuary, although it was less sensitive to human impact than the phytoplankton community. Thus qualitative and quantitative characteristics of phytoplankton and macroalgal blooms can indicate anthropogenic influence on the ecosystem, and help to better manage the Neva estuary.

\section{RÉSUMÉ}

\section{Les cyanobactéries et macroalgues dans l'écosystème de l'estuaire de la Neva}

Mots-clés : phytoplancton, macroalgues, eutrophisation, Planktothrix agardhii, Cladophora glomerata
La mer Baltique et l'estuaire de la Neva sont en proie à l'eutrophisation côtière. Afin d'estimer l'ampleur du problème, des estimations quantitatives du phytoplancton et des macroalgues ont été réalisées dans l'estuaire de la Neva. Le suivi à long terme (1982-2009) du phytoplancton a montré des changements dans sa composition et son abondance. La biomasse estivale a significativement augmenté dans les années 1990, avec des changements concomitants dans la composition des espèces, malgré une baisse de nutriments dans l'estuaire de la Neva. La cyanobactérie Planktothrix agardhii est devenue une espèce dominante. La biomasse estivale de phytoplancton atteint un maximum de 5,2 $\pm 0,4 \mathrm{mg} \cdot \mathrm{L}^{-1}$ en 2002-2004. Le suivi de la communauté de macroalgues dans la zone côtière de l'estuaire de la Neva de 2002 à 2009 a montré la prédominance de l'algue verte filamenteuse Cladophora glomerata dans le phytobenthos La biomasse moyenne de macroalgues dans l'estuaire interne et externe diffère significativement de $132 \pm 29$ et $310 \pm 67 \mathrm{~g} \mathrm{DW} \cdot \mathrm{m}^{-2}$, respectivement. Cette étude a montré que les fluctuations 
de la biomasse des macroalgues traduisent bien l'influence de l'Homme sur l'estuaire, mais elles sont moins sensibles à l'impact de l'Homme que la communauté phytoplanctonique. Ainsi, les caractéristiques qualitatives et quantitatives du phytoplancton et la prolifération des algues macroscopiques peuvent indiquer l'influence anthropique sur l'écosystème, et aider à mieux gérer l'estuaire de la Neva.

\section{INTRODUCTION}

The Baltic Sea and Neva estuary are plagued by coastal eutrophication characterized by intensive growth of green algae in the shallow zone with associated negative consequences. The drifting macroalgae can form loose algal mats or accumulate on beaches, posing a serious threat to both biodiversity and recreation in coastal areas (Norkko et al., 2000; Vahteri et al., 2000; Berglund et al., 2003). Conditions of hypoxia and anoxia, forming under algal mats, result to mortality of benthic fauna (Berezina et al., 2007).

The Neva estuary is a shallow water body with stony-sandy littoral, where stony substrates cover from 10 to $100 \%$ of bottom area. This creates favorable conditions for the development of macroalgae. The first studies of algal diversity macroalgae in the Gulf of Finland, including the Neva estuary, were carried out by Gobi and Grigoriev (1873, 1879), who recorded the green filamentous algae Cladophora sp. and phytoplankton blooms. In the last century it was continued by many researchers (Kiselev, 1924; Makarova, 1997). During recent decades this algae was noticed in most coastal areas of the Neva estuary (Orlova et al., 1999; Golubkov et al., 2003, Gubelit and Kovalchuk, 2010). The first study of macroalgal blooms was conducted from 1998 to 2000 (Orlova et al., 1999; Golubkov et al., 2003) and continued from 2002 to the present time in the present investigation. Our long-term monitoring of phytoplankton (1982 to present time) has coincided with large-scale anthropogenic impact on the ecosystem of the estuary. Qualitative and quantitative changes of phytoplankton community reflected recent human activities (construction of a dam, new ports and dredging works).

This research focuses on the assessment of the presence of two important algal communities in the Neva estuary ecosystem: phytoplankton and macroalgal mats. New data are presented on phytoplankton (2006-2009), macroalgae in outer estuary (2007-2009), and for the first time detailed data on distribution and biomass of macroalgal mats in eastern Gulf of Finland (2005-2009).

\section{MATERIAL AND METHODS}

\section{> STUDY AREA}

The Neva estuary is an easternmost part of the Gulf of Finland, known as an eutrophicated zone of the Baltic Sea. The Neva estuary is divided by artificial and natural bars into an upper part (the Neva Bay) and a lower part (inner and outer estuary) - Figure 1. The situation of the estuarine coast near the city of St. Petersburg results in high level of anthropogenic impacts and eutrophication. The population inhabiting St. Petersburg amounts to five million people, resulting in about $3500 \mathrm{t}$ of phosphorus per year in the Neva River runoff (Frumin, 2008). In 2000 the total phosphorus concentration fluctuated from $41-80 \mu \mathrm{g} \cdot \mathrm{L}^{-1}$ in inner estuary and 24-41 $\mu \mathrm{g} \cdot \mathrm{L}^{-1}$ in outer estuary (Golubkov et al., 2008).

The Neva River originates from Lake Ladoga and flows into the Neva Bay. Time that takes the Ladoga water to reach from the lake to the Neva Bay is about 17-20 h. Therefore the plankton of the Neva Bay reflects Ladoga phytoplankton. The salinity in the Neva estuary increases from Neva Bay (0\%) to the inner $(0.5-1.5 \%)$ and outer estuary (1.8-3.3\%) in the upper water column. 


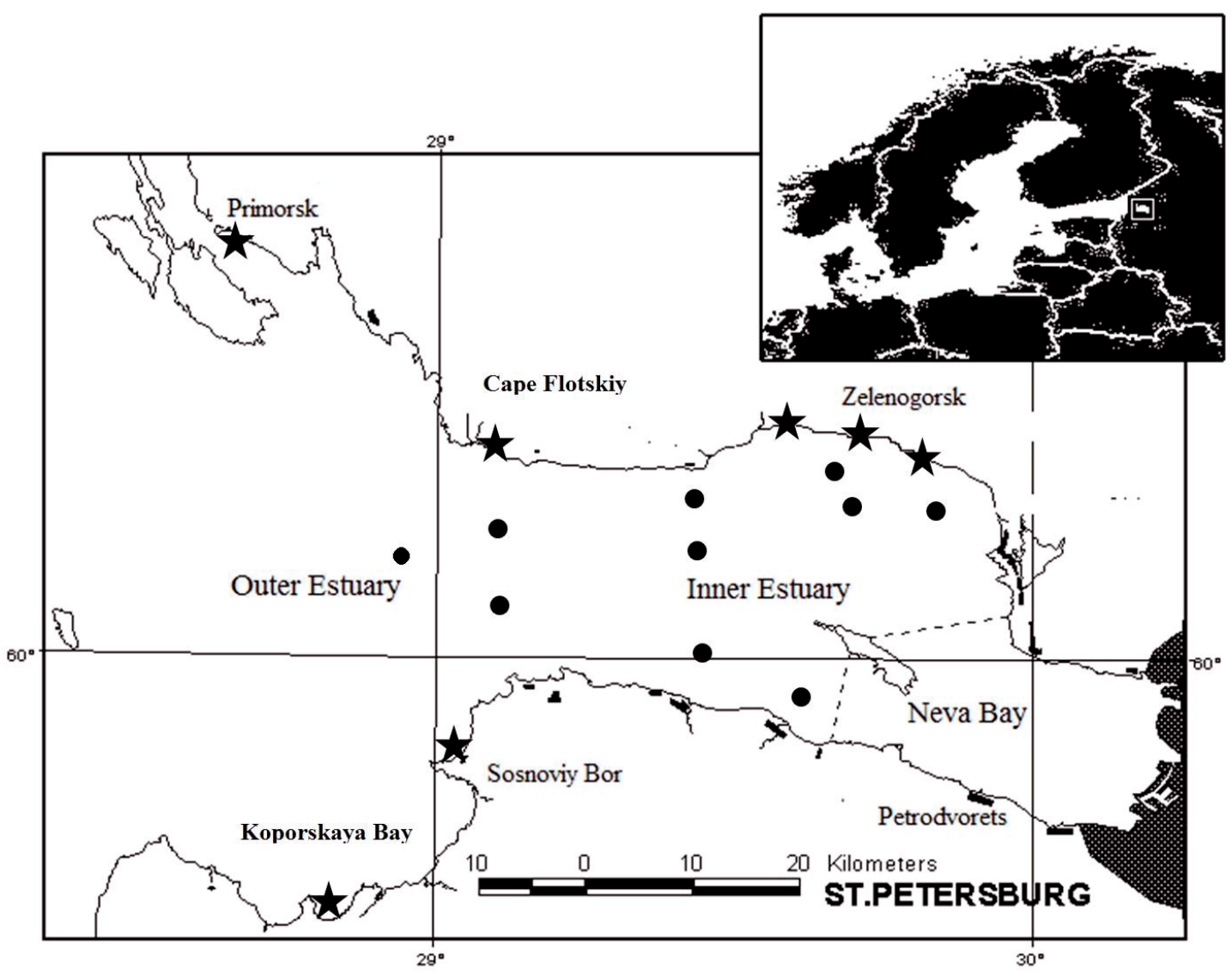

Figure 1

Map of sampling points in the Neva Estuary. The sites of phytoplankton sampling are marked by black dots, the sites of macroalgae sampling are marked by black stars.

\section{Figure 1}

La carte des points d'échantillonnage dans l'estuaire de la Neva. Les sites d'échantillonnage du phytoplancton sont marqués par des points noirs, les sites d'échantillonnage des macroalgues sont marqués par des étoiles noires.

Factors such as salinity and human activity influence the community of planktonic and benthic algae in the Neva estuary. Two main problems in the estuary are cyanobacteria and macroalgal blooms on which is the focus of this study.

\section{> PHYTOPLANKTON MONITORING}

Long-term monitoring of phytoplankton was carried out in three periods: from 1982 to 1988 , from 1997 to 2000 and from 2002 to 2009. Phytoplankton samples (volume 0.2-0.3 L) were collected from the euphotic water layer, with use of a bathometer, and preserved by acid Lugol's solution. The sampling sites marked with black dots (Figure 1).

The phytoplankton taxa were identified and counted in sedimentation chambers $(10-25 \mathrm{~mL})$ with an inverted Hydro-Bios microscope according to Utermöhl (1958). Phytoplankton biomass was calculated in total volume of algal cells, according to Edler (1979), and expressed in WW $\mathrm{mg} \cdot \mathrm{L}^{-1}$. 


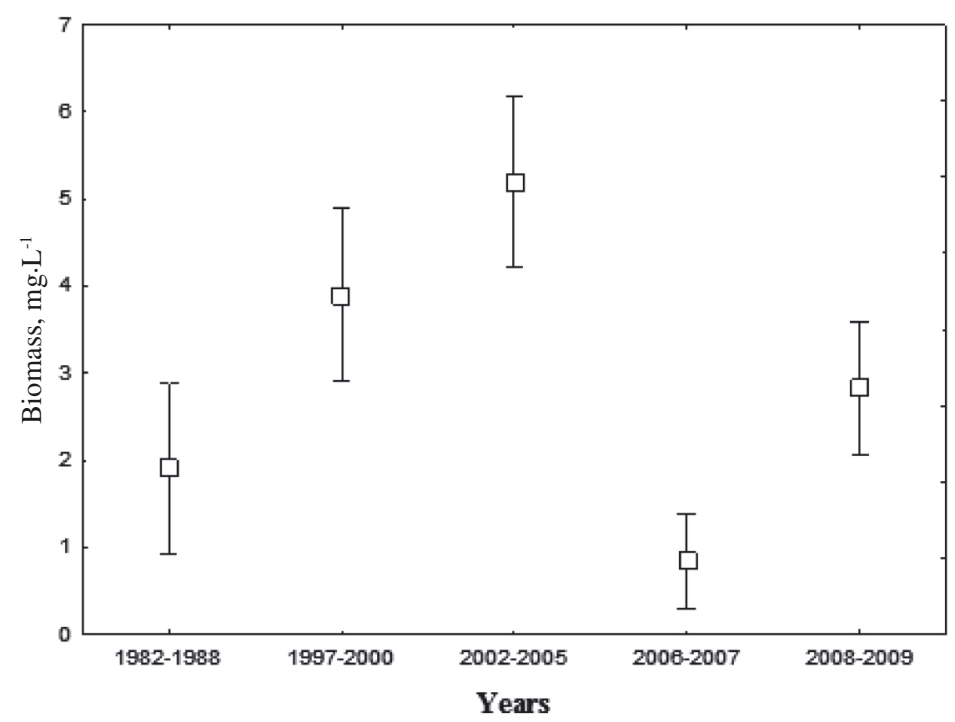

\section{Figure 2}

Average phytoplankton biomass during long-term monitoring in inner Neva estuary. 1982-2005: published data (Nikulina, 1989, 2003, 2008); 2006-2009: new data.

\section{Figure 2}

La biomasse moyenne de phytoplancton au cours du suivi à long terme dans l'estuaire interne de la Neva. 1982-2005 : données publiées (Nikulina, 1989, 2003, 2008); 2006-2009 : nouvelles données.

\section{> SAMPLING OF FILAMENTOUS ALGAE}

Filamentous algae were sampled using a cylindrical metal frame with $0.03 \mathrm{~m}^{2}$ area and scubadiving method in mid-summer period from 2002 to 2009. In 2005-2009 the thickness and biomass of floating algal mats was evaluated. The conditions of hypoxia were determined by the presence of black mud and the smell of hydrogen sulphide.

The sampling sites are marked with black stars in Figure 1. Qualitative sampling was conducted at the depth of 0.5 and $1.5 \mathrm{~m}$. The algae were washed with fresh water and all animals were removed. The samples of algae were then dried to a constant weight in laboratory and weighed $0.01 \mathrm{~g}$ precision. The biomass of the algae was estimated as an arithmetic mean of dry weight $(\mathrm{DW}) \pm \mathrm{SE}$ (standard error) for each date and then recalculated per $1 \mathrm{~m}^{2}$ of substrate.

\section{RESULTS}

\section{> CYANOBACTERIAL BLOOMS}

The abundant blooms of cyanobacteria were observed in the inner estuary. Long-term monitoring in resort area of the inner estuary near the town Zelenogorsk, showed, that the average summer-autumn biomass of phytoplankton significantly increased (Figure 2). In 1982-1988 the biomass was $2 \mathrm{mg} \cdot \mathrm{L}^{-1}$, in 1997-2000 about $3 \mathrm{mg} \cdot \mathrm{L}^{-1}$, and in 2002-2005 $4.5 \mathrm{mg} \cdot \mathrm{L}^{-1}$. In 2006, the phytoplankton community was characterized by poor species composition and extremely low biomass, but in 2008-2009 the biomass of phytoplankton increased again (Figure 2).

During our study, changes in species composition and proportion of different algal groups relative to total biomass were recorded. Contribution from cyanobacteria increased three-fold, bacillariophyta decreased, and cryptophyta increased (Table I). Changes in cyanobacteria species composition are presented in Figures 3A-3C. 


\section{Table I}

Total phytoplankton biomass $\left(B, m g \cdot L^{-1}\right)$ and percentage different algal groups in the total biomass, inner estuary, July-August.

Tableau I

Biomasse totale du phytoplancton $\left(\mathrm{B}, \mathrm{mg} \cdot \mathrm{L}^{-1}\right)$ et pourcentage des différents groupes d'algues dans la biomasse totale, estuaire interne, en juillet-août.

\begin{tabular}{|l|c|c|c|c|c|c|}
\hline Years & $\begin{array}{c}\text { Biomass } \\
\left(\mathrm{mg}^{-L^{-1}}\right)\end{array}$ & Cyanobacteria & Bacillariophyta & Cryptophyta & Chlorophyta & Others \\
\hline $\mathbf{1 9 8 2 - 1 9 8 8}$ & $1.9 \pm 0.2$ & $38.0 \pm 5.5$ & $42.5 \pm 2.6$ & $2.5 \pm 0.1$ & $13.0 \pm 3.2$ & $4.0 \pm 0.9$ \\
\hline $\mathbf{1 9 9 7 - 2 0 0 0}$ & $3.9 \pm 0.8$ & $65.4 \pm 12.6$ & $10.0 \pm 2.1$ & $9.5 \pm 3.2$ & $7.2 \pm 2.5$ & $7.9 \pm 3.1$ \\
\hline $\mathbf{2 0 0 2 - 2 0 0 4}$ & $5.2 \pm 0.4$ & $63.0 \pm 5.6$ & $13.2 \pm 3.3$ & $7.5 \pm 3.4$ & $14.3 \pm 2.2$ & $2.0 \pm 0.5$ \\
\hline $\mathbf{2 0 0 5 - 2 0 0 9}$ & $3.6 \pm 0.8$ & $34.8 \pm 9.8$ & $25.7 \pm 6.1$ & $19.1 \pm 4.2$ & $15.5 \pm 3.5$ & $4.9 \pm 0.6$ \\
\hline
\end{tabular}

\pm- mean error.

a)

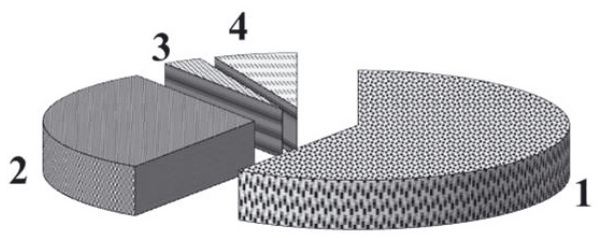

b)

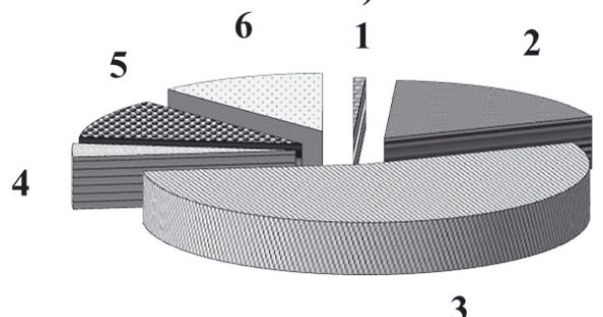

c)

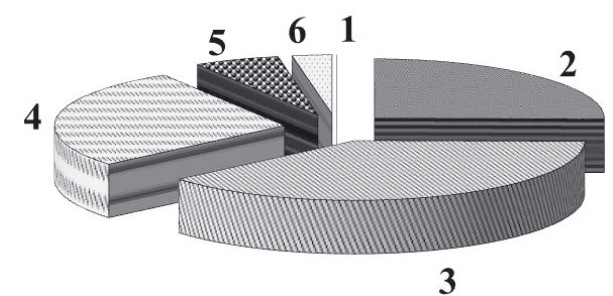

\section{Figure 3}

Proportion of the predominant species cyanobacteria. (a) 1982-1988 (Nikulina, 1989). (b) 19972000 (Nikulina, 2003). (c) 2002-2009 (Nikulina, 2008 and new data): 1, Microcystis aeruginosa. 2, Aphanizomenon flos-aquae. 3, Planktothrix agardhii. 4, Anabaena flos-aquae. 5, Limnothrix planktonica. 6, Planktolyngbia limnetica.

\section{Figure 3}

Proportion des espèces prédominantes de cyanobactéries.

During the first period of monitoring the main contribution to the blooms belonged to nitrogen-fixing species of Microcystis, Anabaena, Aphanizomenon (Figure 3A). In the 1990s nitrogen-fixing algae disappeared (Microcystis aeruginosa) or were reduced (Anabaena), and the species Planktothrix agardhii, Planktolyngbya limnetica, Limnothrix planctonica began 
Biomass, $\mathrm{mg} \cdot \mathrm{L}^{-1}$

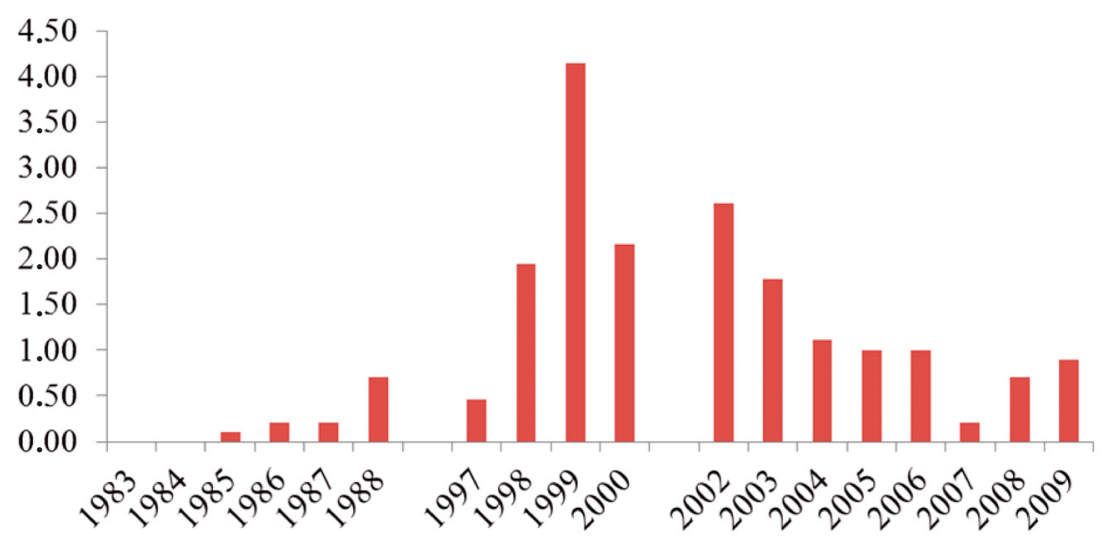

\section{Figure 4}

Biomass of P. agardhii in inner Neva estuary during long-term monitoring: 1983-2005 - published data (Nikulina, 1989, 2003, 2008); 2006-2009 - new data.

\section{Figure 4}

Biomasse de P. agardhii dans l'estuaire interne de la Neva au cours du suivi à long terme : 1982-2005, données publiées (Nikulina, 1989, 2003, 2008); 2006-2009, nouvelles données.

\section{Table II}

Share of P. agardhii and nitrogen-fixing species to cyanobacteria biomass, dependence from water salinity.

\section{Tableau II}

Part des $P$. agardhii et des espèces fixatrices d'azote dans la biomasse des cyanobactéries, dépendance de la salinité de l'eau.

\begin{tabular}{|c|c|c|c|c|c|}
\hline Inner estuary & 2006 & 2007 & 2008 & 2009 & Average \\
\hline Salinity, \%。 & 0.64 & 0.59 & 0.61 & 0.5 & $0.58 \pm 0.06$ \\
\hline Total phytoplankton biomass, $\mathrm{mg} \cdot \mathrm{L}^{-1}$ & 4.4 & 1 & 4.3 & 1.9 & $2.9 \pm 1.71$ \\
\hline Cyanobacteria biomass, $\mathrm{mg} \cdot \mathrm{L}^{-1}$ & 3.4 & 0.46 & 1.52 & 0.86 & $1.56 \pm 1.3$ \\
\hline Share (\%) of Pl. agardhii in cyanobacteria biomass & 67 & 37.5 & 46 & 61.6 & $53 \pm 13.65$ \\
\hline $\begin{array}{l}\text { Share (\%) of nitrogen-fixing species in cyanobacteria } \\
\text { biomass }\end{array}$ & 22.6 & 65.2 & 10.5 & 32 & $32.6 \pm 23.46$ \\
\hline \multicolumn{6}{|l|}{ Outer estuary } \\
\hline Salinity, \%。 & 2.61 & 3.2 & 2.7 & 1.96 & $2.62 \pm 0.51$ \\
\hline Total phytoplankton biomass, $\mathrm{mg} \cdot \mathrm{L}^{-1}$ & 1.62 & 0.78 & 1.88 & 2.01 & $1.57 \pm 0.55$ \\
\hline Cyanobacteria biomass, $\mathrm{mg} \cdot \mathrm{L}^{-1}$ & 1 & 0.2 & 1.55 & 1.2 & $0.99 \pm 0.57$ \\
\hline Share (\%) of $P$ I. agardhii in cyanobacteria biomass & 19 & 11 & 0.2 & 4.1 & $8.58 \pm 8.26$ \\
\hline $\begin{array}{l}\text { Share }(\%) \text { of nitrogen-fixing species in cyanobacteria } \\
\text { biomass }\end{array}$ & 44.2 & 50 & 93 & 73.2 & $65.1 \pm 22.43$ \\
\hline
\end{tabular}

to dominate in the blooms (Figure 3B). In recent years the proportion of Anabaena and Aphanizomenon increased, while Planktothrix decreased (Figure 3C).

The highest values of $P$. agardhii biomass has been observed since the late 1990s to early 2000 s (Figure 4). From the beginning of 2000 s to recent time the surface blooms of nitrogenfixing species $A$. flos-aquae were observed again, as soon as the contribution of $P$. agardhii in overall biomass decreased twice.

Salinity is an important factor that influences the species composition of cyanobacteria in the Neva estuary. With a rise in salinity the proportion of $\mathrm{Pl}$. agardhii in cyanobacteria biomass decreased, while nitrogen-fixing species increased (Table II). 


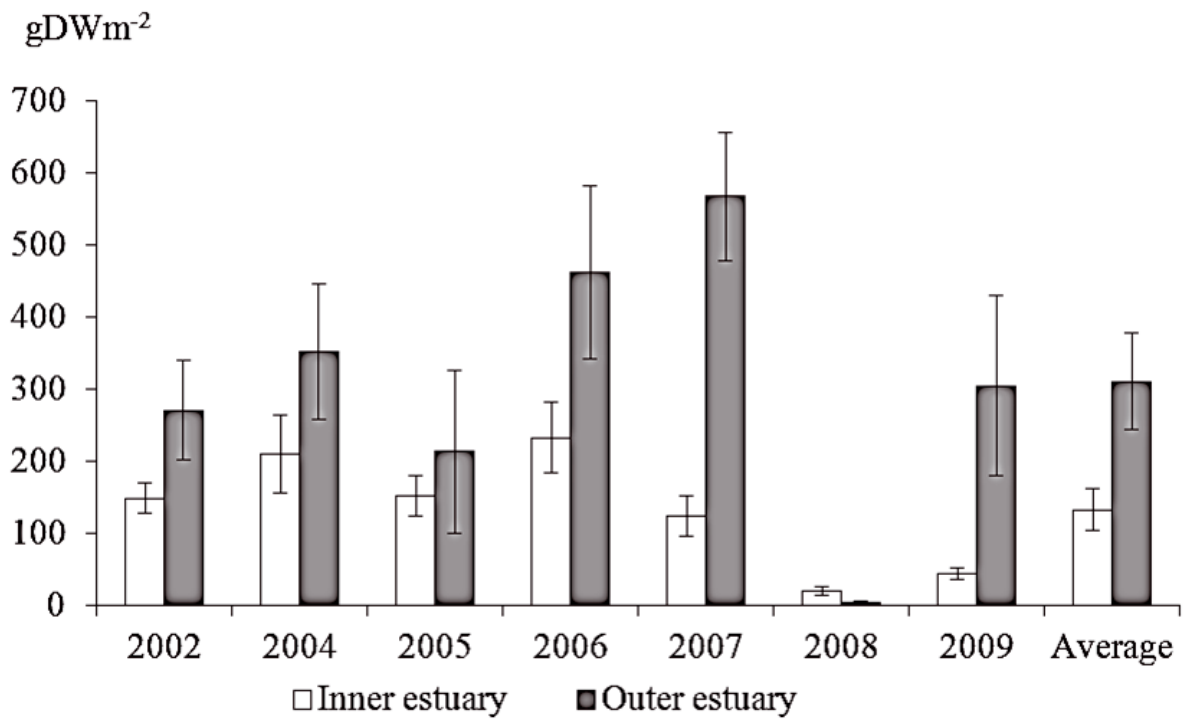

\section{Figure 5}

Biomass of macroalgae in inner and outer Neva estuary. 2002-2006: published data (Gubelit, 2009); 2007-2009: new data.

\section{Figure 5}

Biomasse des macroalgues dans l'estuaire interne et externe de la Neva. 2002-2006 : données publiées (Gubelit, 2009) ; 2007-2009 : nouvelles données.

\section{$>$ MACROALGAL BLOOMS}

Macroalgal blooms were studied from 2002 to 2009, excluding 2003 in outer and inner Neva estuary. Our study showed, that the dominant species in the macroalgal community was Cladophora glomerata in close association with Ulva intestinalis in the inner and outer part of the estuary. In the outer estuary the composition of associated species depended on salinity. When salinity exceeded 2\%, marine species Ceramium sp. and Pylaiella littoralis appeared in the community.

The biomass of macroalgae was significantly different in inner and outer estuary (Figure 5). In inner estuary the interannual fluctuations of biomass differed insignificantly up to 2007. In outer estuary an increase in macroalgal biomass was observed from 2006 to 2007 and reached $567 \pm 88.5 \mathrm{~g} \mathrm{DW} \cdot \mathrm{m}^{-2}$. This value was significantly higher than previous observations from 2002-2005. In 2008 extremely low biomass were recorded, and in 2009 the macroalgal biomass in inner estuary increased insignificantly, but at the same time in outer estuary in 2009 the macroalgae biomass reached similar values to 2002-2005 records (Figure 5).

In 2005-2009 the evaluation of the thickness of algal mats in the estuary was conducted in the Neva estuary. The results are presented in Table III. The most massive accumulation of floating algae was observed in outer estuary near the city Sosnoviy Bor and reached $30 \mathrm{~cm}$ in thickness and $100 \mathrm{~m}$ in width along the coast. In some years the assessment of floating algae biomass was impossible due to decomposition.

The conditions of hypoxia were noted in most of sampling sites, and were attended by massive mortality of benthic animals and fish fry. Despite the high biomass of algal mats on Cape Flotskiy the signs of hypoxia were not observed during all years of the study.

\section{DISCUSSION}

It is known that in mid-latitudes the summer-autumn cyanobacteria bloom is a sign of eutrophication. Maximum development of phytoplankton and cyanobacteria blooms were 
Table III

Characteristics of algal mats in the Neva estuary in 2005-2009.

Tableau III

Caractéristiques du périphyton algal dans l'estuaire de la Neva en 2005-2009.

\begin{tabular}{|l|c|c|c|c|}
\hline Site & $\begin{array}{c}\text { Thickness of algal } \\
\text { mats, } \mathrm{cm}\end{array}$ & $\begin{array}{c}\text { Width of algal } \\
\text { mats, } \mathrm{m}\end{array}$ & $\begin{array}{c}\text { Biomass, } \\
\mathrm{g} \mathrm{DW} \cdot \mathrm{m}^{-2}\end{array}$ & Hypoxia \\
\hline Zelenogorsk & $0-15$ & $10-50$ & $0-1034$ & + \\
\hline Cape Flotskiy & $3-15$ & $10-20$ & $105-1435$ & - \\
\hline Primorsk & $0-20$ & $10-50$ & $0-1074$ & + \\
\hline Sosnoviy Bor & $15-30$ & $10-100$ & $\begin{array}{c}19-468 \\
\text { decaying algae }\end{array}$ & + \\
\hline Koporskaya Bay & $15-30$ & $15-50$ & Decaying algae & + \\
\hline
\end{tabular}

recorded in the northern shallow zone of the Neva estuary near the town Zelenogorsk. In comparison with the 1980s phytoplankton biomass has increased 2-3 times in all areas of the estuary, testifing eutrophication of the ecosystem, caused by both anthropogenic and natural factors (Golubkov et al., 2008; Nikulina, 2008). In 2006 large-scale dredging began in the Neva Bay and continued up to the end of 2007. This caused an abrupt decline of water transparency in the north-eastern part of the inner estuary. As a result, the phytoplankton biomass decreased extremely.

Cyanobacteria bloom in the Baltic Sea and Gulf of Finland was first noted by professor Gobi (1879). Later the summer-autumn bloom was recorded in most of phytoplankton studies, which were conducted in the Gulf of Finland. The ecological assessment of ecosystem requires quantitative evaluation of biomass, abundance and frequency of algal blooms. The abundance and species composition of cyanobacteria are most indicative for estimation of anthropogenic impact.

In our study the rise of phytoplankton total biomass and increase of cyanobacteria proportion may indicate intense eutrophication in the estuary.

In the 1980s the Neva estuary was characterized as a mesotrophic reservoir. Cyanobacteria dominated in August-beginning of September and during this period cyanobacteria blooms became more frequent.

In the 1990s high biomass of cyanobacteria was observed from late June with concomitant changes in bloom-forming species composition. In the 1990s Pl. agardhii produced $60-90 \%$ of the total biomass in the ecosystem of the Neva estuary. A high abundance was recorded for Limnothrix planctonica, Planktolyngbya limnetica, but due to small width of the trichomes $(1.5-2.5 \mu \mathrm{m})$, their contribution to the total biomass was insignificant. The high abundance of Pl. agardhii, P. limnetica, L. planctonica usually indicates eutrophic and polluted waters. The species Aphanizomenon flos-aguae, Aph. gracile, Anabaena circinalis and A. flos-aquae, which can cause a surface bloom, have been less abundant.

According to the literature data, the biomass and abundance of $P$. agardhii rise with increasing of nitrogen loading, organic matter intake and waste water discharge (Edmondson and Lehman, 1981; Chorus and Wesseler, 1988; Varis, 1993; Blomqvist et al., 1994). Thus, in the Lake Kasamigaura (Japan) Microcystis dominated in the plankton, but due to permanent increase of nitrogen loading to the lake, this species was replaced by Pl. agardhii (Sakamoto and Okino, 2000). We also observed a similar shift in species composition of cyanobacteria during our long-term monitoring in the resort area of the Neva estuary.

Changes in species composition of cyanobacteria and predominance of $P$. agardhii in the Neva estuary, according to our researches and literature data, can be the consequence of nitrogen prevalence and organic pollution in the Neva estuary in the 1990s. Changes in species composition of cyanobacteria which was recorded in the 2000s may indicate the decline of organic matter in the inner Neva estuary due to new treatment facilities.

Salinity is another important factor, which influences the development of phytoplankton and especially cyanobacteria. Changes in salinity in the Gulf of Finland results from inflows 
of saline deep water from the North Sea to the Baltic Sea, which occur every few years. This phenomenon also causes phosphorus release from bottom sediments. After inflows the concentration of inorganic phosphorus under the photic layer can increase up to $50 \mu \mathrm{g} \cdot \mathrm{L}^{-1}$ in inner estuary and $120 \mu \mathrm{g} \cdot \mathrm{L}^{-1}$ in outer estuary (Eremina and Karlin, 2008). In the upper layers, especially in the inner Neva estuary, changes in salinity are very small, but sufficient to ensure that the biomass of $P$. agardhii has decreased. Supplementary phosphorus loading from sediments leads to the development of nitrogen-fixing species and formation of surface blooms. The first study of macroalgal blooms in the Neva estuary was conducted in 1998-2001 and was restricted to the inner estuary, resort area near the town of Zelenogorsk. According to this data the biomass of Cladophora glomerata in July fluctuated from 100 to $300 \mathrm{~g} \mathrm{DW} \cdot \mathrm{m}^{-2}$ (Bäck et al., 2001, Golubkov et al., 2003), similarly to our findings from the inner estuary. Dredging works in Neva bay led to an increase of the content of mineral suspension in the water (Golubkov et al., 2008). In comparison with phytoplankton, phytobenthic community did not immediately respond to the human impact. The decline of biomass occurred only in the year following the beginning of dredging works in the estuary, as a result of deposition of mineral suspended matter from water and siltation of the substrate.

The most vulnerable in this case were perennial species of algae (Kovalchuk, 2008). But, despite the fact that the spores and overwintering microscopic stages of green algae of the genera cladophora and ulva are tolerant to the siltation of the substrate (Eriksson and Johansson, 2005), one of the reasons for the abrupt reduction of biomass of green macroalgae in 2008 was probably the deposition of particulate matter from the water at the bottom.

Unlike phytoplankton, the salinity changes were reflected on macroalgae only in outer estuary and impressed by appearance of associated marine species.

Quantitative estimations of algal mats were conducted for the first time in the Neva estuary and complemented previous assessment studies from the Finnish and Estonian coasts of the Gulf of Finland (Lehvo and Bäck, 2001; Paalme, 2005). After the rapid development of macroalgae in shallow water, algal mats become detached from the substrate. The reason for this phenomenon is dependent on environmental conditions.

In the Baltic Sea and the Gulf of Finland the main reason for the break of algae from the substrate is stormy weather (Kiirikki and Lehvo, 1997). The research in the eastern Gulf of Finland 1998-2000 showed that storms disrupted all algae from the substrate (Bäck et al., 2001; Golubkov et al., 2003). In the investigated area the maximum thickness of algal mats in shallow water was $30 \mathrm{~cm}$ (average 10-15 cm) and in width they could reach up to $100 \mathrm{~m}$ (average 15-20 m). According to the data on the Archipelago Sea, the areas with loose-lying algal mats reached more than 30 ha. The coverage of the mats varied between $10-70 \%$ of coastal area, and their thickness was found to vary between 2 and $30 \mathrm{~cm}$ (Vahteri et al., 2000). In our study the feature of the algal mats in the Neva estuary is an absolute dominance of C. glomerata, which reflects the "fresh-face" communities of macroalgae on studied area. In other parts of the Baltic Sea in addition to Cladophora, species such as Ulva spp., P. littoralis, Ectocarpus siliculosus, Ceramium tenuicorne dominated in algal mats (Salovius and Bonsdorff, 2004). In the Neva estuary these species were found in association, but never dominant.

In our study the biomass of the algal mats of the Neva estuary fluctuated from 0 to 1055$1450 \mathrm{~g} \mathrm{DW} \cdot \mathrm{m}^{-2}$. The same biomass of algal mats were also observed in north-eastern Baltic Sea and fluctuated from 35 to $1391 \mathrm{~g} \mathrm{DW} \cdot \mathrm{m}^{-2}$ (Lauringson and Kotta, 2006).

In our study the conditions of hypoxia were recorded in most sites. Gubelit and Berezina (2010) showed, that in inner estuary from the mid of July to the beginning of August anoxic and hypoxic conditions (from 5 to $30 \%$ of oxygen saturation) were observed in habitats under drifting algae. This phenomenon results to the destabilizing fluctuation in zoobenthic biomass due to widespread mortality or offshore migration of animals (Lehvo and Bäck, 2001; Berezina et al., 2007). During the decomposition process (35 days), 40-65\% of phosphorus content in tissue were released by decaying mats of $C$. glomerata (Paalme et al., 2002). Rapid decomposition provides an additional important supply of organic and inorganic compounds potentially available for recycling in the water. 


\section{CONCLUSION}

Our study showed that the quantitative development of some phytoplankton species may be related to the extent of human influence on the estuary. The increase of phytoplankton biomass and extension of cyanobacteria testify of the intensive eutrophication in the Neva estuary during the last two decades.

Planktothrix agardhii is the most important species characterising the conditions of the shallow zone in the Neva estuary. P. agardhii indicates nitrate and organic pollution. After deployment of new treatment facilities the presence of $P$. agardhii decreased. This could indicate a decrease in dissolved organic matter in the estuary.

The community of macroalgae has a freshwater face and is important for the Neva estuary ecosystem. The fluctuations of macroalgal biomass reflected human influence on the estuary, but was less sensitive to human impacts than the phytoplankton community.

Thus qualitative and quantitative characteristics of phytoplankton and macroalgal blooms can indicate anthropogenic influence on the ecosystem. These data will therefore help to better manage the Neva estuary.

\section{ACKNOWLEDGEMENTS}

We thank Dr. Nadezda A. Berezina, Dr. Sergey M. Golubkov and Nickolay A. Kovalchuk for help with sampling. This study was supported by a Presidential Grant (NS-3276.2010.4), the Program of Natural Sciences Department of Russian Academy of Sciences "Fundamentals of the Biological Resources Management", by the Chair Program of the Russian Academy of Sciences "Scientific Fundamentals of the Biodiversity Conservation in the Russian Federation" and Grant of Russian Foundation of Basic Research No. 11-04-00053-a.

\section{REFERENCES}

Bäck S., Anokhina L. and Dernjatin M., 2001. Massive occurences of Cladophora glomerata in the Gulf of Finland, Baltic Sea. In: Abstract Volume Baltic Sea Science Congress, Stockholm, 61 p.

Berezina N., Tsiplenkina I.G., Pankova E.S. and Gubelit J.I., 2007. Dynamics of invertebrate communities in stony littoral of the Neva estuary (Baltic Sea) under macroalgal blooms. Transit. Waters. Bull., 1, 49-60.

Berglund J., Mattila J., Rönnberg O., Heikkilä J. and Bonsdorff E., 2003. Seasonal and inter-annual variation in occurrence and biomass of rooted macrophytes and drift algae in shallow bays. Est. Coast. Shelf Sci., 56, 1167-1175.

Blomqvist P., Petersson A. and Hyenstrand P., 1994. Ammonium-nitrogen: A key regulatory factor causing dominance of non-nitrogenfixing cyanobacteria in aquatic system. Arch. Hydrobiol., 132, 141164.

Chorus I. and Wesseler E., 1988. Response of the phytoplankton community to the rapy measures in a highly eutrophic urban lake (Schlachtensee, Berlin). Verh. Internat. Vereinig. Limnol., 23, 719-728.

Edler L., 1979. Recommendations for marine biological studies in the Baltic Sea. Phytoplankton and chlorophyll. Baltic Marine Biologists Publication, 5, 1-38.

Edmondson W.T. and Lehman J.T., 1981. The effect of changes in the nutrient income on the condition of Lake Washington. Limnol. Oceanogr., 26, 1-29.

Eremina T.R. and Karlin L.N., 2008. Contemporary aspects of hydrochemical conditions in the eastern Gulf of Finland. In: Alimov A.F. and Golubkov S.M. (eds.), Ecosystem of the Neva Estuary: Biological Diversity and Ecological Problems, KMK, St. Petersburg-Moscow, 24-38 (in Russian).

Eriksson B.K. and Johansson G., 2005. Effects of sedimentation on macroalgae: species-specific responses are related to reproductive traits. Oecologia, 143, 438-448. 
Frumin G.T., 2008. Dynamics of nutrients in the Neva Bay from the runoff of the Neva River and its branches. In: Alimov A.F. and Golubkov S.M. (eds.), Ecosystem of the Neva Estuary: Biological Diversity and Ecological Problems, KMK, St. Petersburg-Moscow, 20-23 (in Russian).

Gobi Kh.Ya., 1879. A brief report on the trip undertaken in summer 1878 with algological purpose. Proceedings of St. Petersburg Society of naturalists, 10, 93-97 (in Russian).

Gobi Kh.Ya. and Grigoriev A.V., 1873. Preliminary report by Gobi K.Y. and Grigoriev A.V. on joint survey to northern shore of the Gulf of Finland in summer 1872 for algological researches. Proceedings of St. Petersburg Society of naturalists, 4, 122-138 (in Russian).

Golubkov S.M., Bäck S., Nikulina V.N., Orlova M.I., Anokhina L.E. and Umnova L.P., 2003. Effects of eutrophication and invasion of Dreissena polymorpha in the coastal zone of the eastern Gulf of Finland. Proc. Estonian Acad. Sci., 52, 284-304.

Golubkov M.S., Golubkov S.M. and Umnova L.P., 2008. Primary production and problems of eutrophication of the Neva estuary. In: Alimov A.F. and Golubkov S.M. (eds.), Ecosystem of the Neva Estuary: Biological Diversity and Ecological Problems, KMK, St. Petersburg-Moscow, 313-338 (in Russian).

Gubelit Yu.I., 2009. Biomass and primary production of Cladophora glomerata (L.) Kütz. in the Neva estuary. Inland Water Biol., 2, 300-304.

Gubelit Yu.I. and Berezina N.A., 2010. The causes and consequences of algal blooms: the Cladophora glomerata bloom and the Neva estuary (eastern Baltic Sea). Mar. Pollut. Bull., 61, 183-188.

Gubelit Yu.I. and Kovalchuk N.A., 2010. Macroalgal blooms and species diversity in the Transition Zone of the eastern Gulf of Finland. Hydrobiologia, 656, 83-86.

Kiirikki M. and Lehvo A., 1997. Life strategies of filamentous algae in the northern Baltic proper. Sarsia, 82, 259-267.

Kiselev I.A., 1924. Phytoplankton of Neva Bay and eastern part of the Gulf of Finland. In: Investigation of Neva River and its Basin, Part 2, Leningrad, 3-54 (in Russian).

Kovalchuk N.A., 2008. Biodiversity and the Current State of the Green, Brown and Red Macroalgae in the Russian Sea Area of the Gulf of Finland. In: Alimov A.F. and Golubkov S.M. (eds.), Ecosystem of the Neva Estuary: Biological Diversity and Ecological Problems, KMK, St. Petersburg-Moscow, 126-136 (in Russian).

Lauringson V. and Kotta J., 2006. Influence of the thin drift algal mats on the distribution of macrozoobenthos in Kõiguste Bay, NE Baltic Sea. Hydrobiologia, 554, 97-105.

Lehvo A. and Bäck S., 2001. Survey of macroalgal mats in the Gulf of Finland, Baltic Sea. Aquatic Conservation Marine Freshwater Ecosystems, 11, 11-18.

Makarova S.V., 1997. Species composition and quantity characteristics of phytoplankton. In: The Problems of Investigation and Mathematical Modeling of Baltic Sea Ecosystem, Part 5, Ecosystem models, Evaluation of modern conditions in the Gulf of Finland II, Hydrometeoizdat, St. Petersburg, 354-365 (in Russian).

Nikulina V.N., 1989. Blue-green algae in the eastern Gulf of Finland. Tr. Zool. Inst. Akad. Nauk SSSR, 205, 26-35 (in Russian).

Nikulina V.N., 2003. Seasonal dynamics of phytoplankton in the inner Neva Estuary in the 1980s and 1990s. Oceanologia, 45, 25-39.

Nikulina V.N., 2008. Phytoplankton of the Neva estuary. In: Alimov A.F. and Golubkov S.M. (eds.), Ecosystem of the Neva Estuary: Biological Diversity and Ecological Problems, KMK, St. Petersburg-Moscow, 76-96 (in Russian).

Norkko J.E., Bonsdorff E. and Norkko A., 2000. Drifting algal mats as an alternative habitat for benthic invertebrates. Species specific responses to a transient resource. J. Exp. Mar. Biol. Ecol., 248, 79-104.

Orlova M.I., Anokhina L.E., Panov V.E., Nekrasov A.V. and Klimentenok S.N., 1999. Preliminary environmental state assessment for littoral zone in Resort District of St. Petersburg. Research Bulletin of the Baltic Floating University, 3, 37-42.

Paalme T., 2005. Nuisance brown macroalga Pilayella littoralis: primary production, decomposition and formation of drifting algal mats, Ph.D. thesis, Tallinn University, Tallinn, Estonia. 
Paalme T., Kukk H., Kotta J. and Orav H., 2002. "In vitro" and "in situ" decomposition of nuisance macroalgal Cladophora glomerata and Pilayella littoralis. Hydrobiologia, 475/479, 469-476.

Sakamoto M. and Okino T., 2000. Self-regulation of cyanobacterial blooms in a eutrophic lake. Verh. Int. Verein. Limnol., 27, 1243-1249.

Salovius S. and Bonsdorff E., 2004. Effects of depth, sediment and grazers on the degradation of drifting filamentous algae (Cladophora glomerata and Pilayella littoralis). J. Exp. Mar. Biol. Ecol., 298, 93-109.

Utermöhl H., 1958. Zur Vervollkommnung der quantitativen Phytoplankton - Methodik. Mitt. Int. Ver. Limnol., 9, 1-38.

Vahteri P., Mäkinen A., Salovius S. and Vuorinen I., 2000. Are drifting algal mats conquering the bottom of the Archipelago Sea, SW Finland? Ambio., 29, 338-343.

Varis O., 1993. Cyanobacteria dynamics in a restored Finnish lake: a long term simulation study. Hydrobiologia, 268, 129-145. 